Reviews

nutrient recycling, pest control and pollution services and the like. For these insights, he is to be applauded, but Zovanyi seems altogether too satisfied with finding the right linguistic formula for sustainability, leaving us wondering about the vast array of policies - international agreements, macroeconomic controls, reproduction and family size policies, agriculture, energy, industry, forestry, land use, and so forth - that might contribute to the ecological vision. He spends much of his last chapter repeating his disappointment in the planning profession, but he might have served us better with policy-oriented advocacy. With this omission, Zovanyi proves himself a better historian than futurist.

\title{
Critical Masses: Opposition to Nuclear Power in California, 1958-1978, by Thomas Raymond Wellock. The University of Wisconsin Press, 1998. xi, 333 pp.
}

\section{Reviewed by Paula Garb, Department of Environmental Analysis and Design, University of California, Irvine.}

Critical Masses is the first detailed historical study of the US anti-nuclear movement. It is also the first state-level research on the subject with a focus on California and its coastal battlefields marked by abandoned nuclear sites. The book is rich with vivid verbal pictures and the passionate voices of participants on all sides of the controversy around the peaceful atom. It is based on interviews, documents from state and federal archives, and activist papers. Wellock brings to this project the expertise of a former engineer for civilian and navy nuclear reactors, a thorough archivist, and a sensitive interviewer. Clearly he won the trust of his interlocutors, the key actors in this twenty-year drama, from whom he elicited intimate and insightful accounts. Wellock is also adept at pointing out the regional differences in culture and politics in these diverse California communities, which is so important in explaining the methods and rhetoric of protest. These are the qualities that make this book so persuasive and compelling to read.

The central argument is that the anti-nuclear movement played an important role in the demise of nuclear power. Wellock disagrees with scholars, the press and even activists who typically claim that the nuclear power industry would have collapsed even if there had not been an anti-nuclear movement. Often these studies focus on the economic and institutional factors, and view the anti-nuclear movement as secondary. Some authors maintain that the protest movements at nuclear facilities effectively captured public attention, but were too weak to be formidable adversaries against the centralized and powerful nuclear establishment. Wellock presents a strong case against this approach. He takes us into the halls of the US regulatory system, which he maintains was not as strong as its critics thought, and shows how activists in league with sympathetic regulators and politicians outflanked the federal government's authority over nuclear power construction.

Wellock's study looks at movements at the local level where he claims the role of decentralization is most apparent. It focuses on the influence and roots of these movements. His in-depth accounts of local activism illustrate how post-World War II education and affluence promoted among the public the values of environmental consciousness that opposed the nuclear 


\section{Reviews}

industry's philosophy of unlimited economic growth. This new environmental consciousness motivated popular demands for a safe, clean and scenic environment. These values provided the ideological strength that drove this movement. They appealed both to progressive environmentalists and populists who had anti-federal sentiments. Non-materialist values eventually influenced state structures, politics, and scientific research, and won over key politicians and scientists. Wellock shows us how anti-nuclear activists and state government institutions altered the fundamental nature of energy policy in the state.

The first half of book takes us from 1958 to 1973. It describes the evolution of the movement from one that objected to the way a power plant looked to one that was environmentally and political conscious. After 1973, we see how anti-nuclear activism broadened beyond its environmental base motivating citizens to work through state and local institutions for political reform to defeat nuclear power projects.

Wellock traces the birth of the anti-nuclear movement to the battle over Pacific Gas \& Electric's attempt in Bodega Bay to build the nation's first commercially viable nuclear power plant. This battle began in 1958 and ended in 1964, with the forced abandonment of these plans. Attempts to build a nuclear power plant in Malibu were similar to those at Bodega Bay and had the same fate. The difference was that, unlike Bodega, which was a backwater fishing village, Malibu was the home of movie stars and other individuals who wanted to protect land values and the lifestyles of the wealthy property owners. They saw economic value in the non-materialist enjoyments of the land. What these cases had in common was that they gave nuclear power the image of a dirty, soiled, dangerous force that could not be allowed into communities. Wellock points out that these protests clouded the future of nuclear power in California.

The movement grew qualitatively in California between 1964 and 1974. In Wellock's detailed history of that period we understand the controversies within the Sierra Club over how to lead this movement, and its subsequent split over disagreements in the Diablo Canyon battle, which ended in victory for the utilities. The result of the split led to the formation of Friends of the Earth, which signaled the transformation of the movement into "born-again anti-nuclearists," a term that Wellock got from David Brower, the militant environmentalist who established Friends of the Earth when he resigned from the Sierra Club. It was also during this period that scientists and engineers began supporting the intuitive positions of the activists. They were also influenced by the nonmaterial philosophy that had inspired activists and impacted the public consciousness. They did not support the country's growth oriented priorities, and wanted to use their expertise in the service of this cause.

The energy crisis of the early 1970s provided an opening for environmental laws. The federal government procrastinated in developing a comprehensive energy policy, which benefited California, ready to push new energy legislation. Energy regulation sympathetic to the environmental movement's values was greatest in California, and developed alongside the antinuclear movement. Throughout the seventies the energy bureaucracy and anti-nuclear movement nurtured and protected each other. California had the resources to develop government programs against nuclear power, and was a pioneer in developing alternative energy sources, conservation, and utility regulation.

With a strong energy policy the movement was able to expand its constituency beyond core environmentalists and scientists to include the former New Left, peace groups and religious organizations. The California referendum in 1976 against nuclear power coincided with this build up. Although the initiative lost (with one-third of the voters supporting it) it showed that more Americans were uncertain about the old values of unlimited economic growth.

Wellock's fascinating step-by-step account, which draws a convincing link between activism and change, concludes with the final major victories of the California anti-nuclear movement. He regards the Sundesert project in San Diego to be the culmination of trends that had been developing since the battle for Bodega. It was also the first time a major politician, in this case California's governor Jerry Brown, used his office to stop a nuclear plant. He regards this as the culmination of trends that had been developing since the battle for Bodega. The author's final 
Reviews

story is about how the fight for community control and nuclear power in Wasco, in California's Central Valley, northwest of Bakersfield, marked the transformation of the movement into the voice of a general public sentiment against nuclear power.

\section{The Political Ecology of Bananas: Contract Farming, Peasants, and Agrarian Change in the Eastern Caribbean. By Lawrence S. Grossman. Chapel Hill: University of North Carolina Press (1998) xviii, 268 pp.}

\section{Reviewed by Mark Moberg, Department of Sociology and Anthropology, University of South Alabama}

Until the early 1980s, the persistence of "peasants" in the commercial agricultural sectors of postcolonial societies prompted acrimonious debate among political economists. Are small-scale farmers who rely on household labor destined to extinction in competition with larger capitalist farms, as Marx originally argued? Are they a source of "spontaneous capitalism," prone to social differentiation into proletarians and commercial farmers, as Lenin claimed? Conversely, are they able to out-compete commercial farms due to their famed capacity for "self-exploitation," as Chayanov had contended? Finally, many neo-Marxists, such as Deere and De Janvry, challenged the very terms of the debate by noting that what appeared to be rural cultivators were in fact "disguised" or semi-proletarians. As De Janvry (1981) observed in the most compelling contribution to the exchange, the peasant question is fraught with practical and political implications that far exceed the semantics of the debate. Indeed, the exchange may have been so exceptionally fervent because it recapitulated Soviet policy debates that ended in collectivization and the persecution of scholars and policy-makers who favored a smallholder-based rural economy.

If the peasant studies debate of the 1970s and 80s vanished into the post-structuralist tide that later overtook the social sciences, the issues it raised, like the peasantry itself, have stubbornly refused to go away. Recent decades have actually witnessed an expansion of peasant involvement in commercial agriculture in much of the developing world, seemingly in defiance of political economists' predictions of a "disappearing" peasantry or one that is consigned to staple production. Are such trends a vindication of Chayanov and final refutation of Marxist political economy? In The Political Ecology of Bananas, Lawrence Grossman demonstrates that peasant persistence in export production is related less to the resilience of household economies than to the interests of the multinational firms that market peasant produce in the developed world. Grossman's book is one of several recent studies examining a significant structural change occurring in tropical agriculture over recent decades: the shift from vertically-integrated plantation production under direct corporate control to various forms of sub-contracting, often involving household-based units of production. Such arrangements have been initiated by most of the corporations that dominate world markets in crops such as bananas, coffee, cacao, citrus and sugar, and are now commonplace in Africa, Asia, Latin America, as well as the Eastern Caribbean context that Grossman documents.

Unlike the earlier peasant studies literature, which remained at the levels of household and national economies, recent analyses have situated contract farming within the changing framework 